\title{
(Re)Learning to Live Together in 2020
}

\author{
Darla K. Deardorff \\ Duke University, USA
}

We must learn to live together as brothers, or perish together as fools. - Martin Luther King Jr.

Ten years ago, the world was quite a different place with the devastation of a 7.0 magnitude earthquake in Haiti, the exuberance of the 2010 Winter Olympics in Vancouver, the release of the first iPad, the launch of Instagram, and the beginning of Arab Spring. Fast forward to 2020 and not only is it the $10^{\text {th }}$ anniversary of the Journal of International Students, but the world is facing unprecedented times with a global pandemic that has illustrated the interconnectedness of humankind like never before. We have all been reminded of the power of human connection as we experience isolation, confinement, social distancing, and even fear. We have witnessed powerful images of front-line workers giving their all, and neighbors in cities and towns across the world connecting from balconies and through windowpanes. These images have reminded us how much our lives depend on those around us, and how important it is that we renew our efforts in learning how to live together.

These challenging months have been an opportunity for us to reflect upon what matters most, what bonds us all together, and what it means to be a good neighbor. For international educators, 2020 has not only challenged us but also provided opportunities to re-think and re-imagine international education in a troubled $21^{\text {st }}$ century. For international students, 2020 has not only wreaked havoc on study plans but some have faced challenging situations of increased xenophobia and discrimination in their host countries.

Many questions have been raised through all of this and many are yet to come given the uncertainty we continue to face. One key question I keep returning to is this: What does it mean to live together, especially now? We, as international educators, have tried to address this question through our efforts in advancing global learning, intercultural competence and global citizenship. Yet, even then, 
these efforts have been primarily directed toward domestic students with less intentionality in including international students in such efforts. The pandemic has illuminated some of what may be missing in these efforts to date. For example, it is natural as educators that we focus on knowledge, learning, teaching, activities, and experiences. Within the literature on intercultural and global competence, definitions focus on knowledge, skills, and attitudes. Increasingly, there is research about social-emotional learning, emotional intelligence, and discussion around empathy. Yet, it seems like empathy may not be enough, emotional intelligence may not be enough, and intercultural competence and global citizenship may not be enough. What seems to be missing in all of this, is perhaps how we view others and how we view ourselves in relation to others. It illuminates the theme of connection, which has been demonstrated so powerfully over this last year. What if we viewed ourselves through the lens of "we" given our interconnectedness? What if we viewed others through the lens of neighbor, both our local and global neighbors? This could shift our way of thinking about global citizenship and make it more real.

Neighborliness is a term not often found in current Western literature and yet this value dates back to the earliest days of humanity. Ancient literature discusses the importance of loving one's neighbor - both Confucius and Jesus said "Love thy neighbor as thyself" with religions noting the importance - and even centrality - of loving one's neighbor. This is not just the purview of religion. In the $17^{\text {th }}$ century, famous Enlightenment philosopher John Locke (1977) stated, "to love our neighbors as ourselves is such a truth for regulating human society, that by that alone one might determine all cases in social morality." How do we behave toward our neighbors - locally and globally? What does it mean to be a "good neighbor?" Even more than that, how might the world be different if humans actually practiced loving their neighbors (and enemies) and putting others' needs as equal to their own? This "loving one's neighbor" goes far beyond greeting card sentiment. It is hard and sometimes even dangerous work, when such love means standing up for what's right, sacrificing for others' good, and even risking one's life, as in the case of healthcare workers today. As Martin Luther King Jr (1963) observed, "The true neighbor will risk his position, his prestige and even his life for the welfare of others. " Company CEOs and business leaders also see that love works. Joel Manby (2012), as a CEO, writes about seven timeless principles connected to this transformational way to lead: through patience, kindness, trust, unselfishness, truth, forgiveness, and dedication. The challenge for international educators is to explore how these principles of loving one's neighbor translate into programs and practices.

And what might this look like within international education? To answer that question, we can draw from the humanistic value of ubuntu, originating from South Africa, which sees humanity as bound together. Desmond Tutu (n.d.) explains this term in the following way:

Ubuntu speaks particularly about the fact that you can't exist as a human being in isolation. It speaks about our interconnectedness. You can't be human all by yourself, and when you have this quality - ubuntu- you are known for your generosity. We think of ourselves far too frequently as 
just individuals, separated from one another, whereas you are connected and what you do affects the whole world. When you do well, it spreads out; it is for the whole of humanity.

Other cultures have similar concepts such as kizuna (Japanese), siratulrahim (Malay), alli kawsay, nandereko and buen vivir (Andean). This concept goes a step further to a deeper identity of an interconnected human being living within community. This becomes a paradigm shift from "me" to "we," a shift that has been emphasized during the pandemic. It becomes imperative that we move beyond an "us" versus "them" mindset to seeing the common humanity of all. As international educators, how can we reframe our work to more of a "we" approach that emphasizes community - or even as Martin Luther King Jr, said "the beloved community?"

Desmond Tutu's granddaughter Mungi Ngomane (2020) writes about living everyday ubuntu in community by implementing several actions: see yourself in others, choose to see the wider perspective, put yourself in the shoes of others, believe in the good of everyone, embrace our diversity, seek out ways to connect, remember the power of forgiveness, and acknowledge reality. Many of these actions already exist in much of the work of international educators who can be even more intentional about addressing these actions through internationalization efforts that focus more explicitly on our shared humanity. Let's embrace this opportunity to rethink and reimagine what it means to truly care for each other and this planet we share, through building deeper relationships as local and global neighbors and through living in authentic community as we re-commit to learning to live together.

Love and compassion are necessities, not luxuries.

Without them, humanity cannot survive. - Dalai Lama

\section{REFERENCES}

King, Jr. M. L. (1963). Strength to love. Harper \& Row.

Locke, J. (1977). The Locke reader: Selections from the works of John Locke. Cambridge University Press.

Manby, J. (2012). Love works: Seven timeless principles for effective leaders. Zondervan.

Ngomane, M. (2020). Everyday ubuntu: Living better together, the African way. Harper.

Tutu, D. (n.d.). Ubuntu. Tutu Foundation UK. http://www.tutufoundationuk.org/ubuntu/

DARLA K. DEARDORFF, EdD, is a research scholar with the Social Science Research Institute at Duke University, and the executive director of the Association of International Education Administrators. She is an internationally recognized expert on intercultural competence, global leadership, and international education 
assessment. With 8 books and 60+ articles, her most recent book entitled Manual for Developing Intercultural Competencies: Story Circles (Routledge/UNESCO, 2020open access) highlights a new tool, Story Circles, that is being used worldwide in the development of intercultural competencies to bridge divides and build community. Email: d.deardorff@duke.edu; www.iccglobal.org 